\title{
Identifying the Monotonic Trend in Climate Change Parameter in Kluang and Senai, Johor, Malaysia
}

(Mengenal Pasti Tren Berekanada di dalam Parameter Perubahan Iklim di Kluang dan Senai, Johor, Malaysia)

\author{
FIRDAUS MOHAMAD HAMZAH*, FARAHANI MOHD SAIMI \& OTHMAN JAAFAR
}

\begin{abstract}
Presently, climate change plays an important role as it gives a serious impact to the living things on earth. Analyzing the trend of climate change is very important in identifying the pattern of changes because it can give an initial overview for future analysis. In this study, trend analysis was carried out to study the pattern of changes for five climate change parameters, such as total amount of monthly precipitation $(\mathrm{mm})$, monthly average temperature $\left({ }^{\circ} \mathrm{C}\right)$, monthly average global radiation $\left(\mathrm{MJm}^{-2}\right)$, monthly average wind speed $(\mathrm{m} / \mathrm{s})$ and monthly average humidity $(\%)$ during the period of 1974 to 2010. Comparisons were made between two research stations, which were the Senai International Airport and Kluang Meteorological Stations. In this study, the Mann-Kendall trend test and Sen's slope estimator test were used to identify the monotonic trend for the se climate change parameters. As a result of this analysis, the precipitations showed no trend for both locations and the radiation showed no trend in Kluang from both analyses. Meanwhile, other parameters in Senai and Kluang showed a monotonic trend, according to the Tau value (Z) and the Sen's slope value. The temperature shows a positive trend for both locations.
\end{abstract}

Keywords: Climate change parameter; Mann-Kendall trend test; monotonic trend; non-parametric trend estimator; Sen's slope estimator test

\section{ABSTRAK}

Perubahan iklim memainkan peranan yang penting pada masa kini berikutan kesan serius terhadap kehidupan di bumi. Analisis tren perubahan iklim amat penting dalam mengenal pasti perubahan coraknya kerana analisis ini dapat memberi gambaran awal dalam membuat analisis lanjutan. Dalam kajian ini, analisis tren dilakukan untuk melihat perubahan iklim bagi parameter perubahan iklim, iaitu jumlah jatuhan hujan bulanan $(\mathrm{mm})$, purata suhu bulanan $\left({ }^{\circ} \mathrm{C}\right)$, purata radiasi global bulanan $\left(\mathrm{MJm}^{-2}\right)$, purata kelajuan angin bulanan $(\mathrm{m} / \mathrm{s})$ serta purata kelembapan bulanan $(\%)$ sepanjang tempoh 1974 sehingga 2010. Perbandingan dibuat antara dua stesen kajian, iaitu stesen meteorologi Lapangan Terbang Antarabangsa Senai dan Stesen Meteorologi Kluang. Dalam kajian ini, ujian tren Mann-Kendall dan ujian anggaran kecerunan Sen digunakan bagi melihat tren parameter perubahan iklim. Keputusan daripada analisis ini menunjukkan tiada tren parameter hujan bagi kedua-dua kawasan dan radiasi juga tidak menunjukkan tren keputusan daripada kedua-dua analisis. Manakala parameter lain menunjukkan tren berekanada di Senai dan Kluang berdasarkan nilai Tau (Z) dan nilai kecerunan Sen. Tren positif ditunjukkan bagi suhu di kedua-dua kawasan.

Kata kunci: Anggaran tren tak berparameter; parameter perubahan iklim; tren berekanada; ujian anggaran kecerunan Sen; ujian tren Mann-Kendall

\section{INTRODUCTION}

Knowledge in the field of meteorology is important because it will affect both human life and the development of the country. Over the years, climate change has become a major topic of discussion (Pin et al. 2013). The analysis of climate change has increasingly attracted the attention of many researchers due to their concerns over the impact of climate change on human and environment in the present and the future. It may cause major changes in climatic variables such as precipitation (Heim 2015) air temperature (Fonseca et al.2016), relative humidity and solar radiation (Haskett et al. 2000). Climate change is one of the most serious challenges faced by humanity in the 21 st century (Vo et al. 2015) where it gives a serious impact to human health, natural ecosystems, agriculture, water resources (Ikhwanuddin et al. 2016), occurrence of harmful algae in water (Soon \& Ransangan 2016), energy consumption, transport (Jarvis et al.2008), increase of temperature of the region (Bachelet et al. 2016), increase of the hydrological cycle (Apurv et al. 2015), effects on landslide activity (Rianna et al. 2014) and energy consumption (Shibuya \& Croxford 2016). Chandler and Scott (2011) claimed that investigating the trend of climate change parameter is important to understand the climatology history for future predictive.

In Malaysia, floods and flash floods occur in tradition, especially in the east coast areas during the monsoon season (Gasim et al. 2010). However, the recent severe 
flooding that occurred in Johor is the result of a new weather phenomenon caused by heavy rain brought by winds from the South China Sea and the western Pacific Ocean (The Star 2006). Typhoon Utor is the main factor leading to the severe floods in Johor and Malaysia in 2006 and 2007 (Amirullah 2011). According to the Federal Department of Town and Country Planning Peninsular Malaysia (2011), typhoon Utor was said to be the main source of this extraordinary rain, where it caused rainfall drops to be above the usual level, which is $350 \mathrm{~mm}$ within $24 \mathrm{~h}$. Eventually, the water level will rose immediately cause major floods in these locations.

According to the report presented by the Malaysian Meteorological Department (2014), there are some obvious effects of climate change such as an increase in average annual temperature in Peninsular Malaysia by $0.02^{\circ} \mathrm{C}$, which is equivalent to $2^{\circ} \mathrm{C}$ per 100 years. Additionally, a report from the National Hydraulic Research Institute of Malaysia (NAHRIM) showed there has been an increasing amount of rainfall since 2000 by $17 \%$ as compared to 1970 (Shaaban 2013). This is one example of the rapid effects of climate change in Malaysia.

Therefore, understanding the trends and future trends of climate change parameters would help researchers or meteorologists produce better planning in dealing with the climate change phenomenon. The techniques of trend detection has attracted the attention and interest of researchers over the decades (Jamaludin et al. 2010), particularly in the studies of climate change such as temperature and precipitation (Anghileri et al. 2014; Onyutha et al. 2015; Rosmann et al. 2016). They have also proposed to use sophisticated methods such as parametric models (deterministic trend), non-parametric estimated trend and stochastic trend in order to avoid any confusion when concluding the trend analysis.

In a nutshell, the objective of this research was to utilize the Mann-Kendall trend test to investigate the monotonic trend in the climate change parameter, while Sen's slope estimator was used to estimate the changes of the climate change parameter by comparing the result with the Mann-Kendall trend test. A comparison was made between the Mann-Kendall trend test and Sen's slope estimator as the Mann-Kendall statistical test has been frequently used to quantify the significance of trends in hydro-meteorological time series (Mondal et al. 2012; Yue et al. 2002). While Sen's slope estimator has been widely used in hydro-meteorological time series (Tabari et al. 2011). The climate change parameters used in this study were the total amount of monthly precipitation ( $\mathrm{mm}$ ), monthly average temperature $\left({ }^{\circ} \mathrm{C}\right)$, monthly average of global radiation $\left(\mathrm{MJm}^{-2}\right)$, monthly average wind speed $(\mathrm{m} / \mathrm{s})$ and monthly average humidity (\%) during the period of 1974 to 2010 . A comprehensive analysis among the climate parameters was performed in this study. The changes in the monotonic trend have been carried out in the results that were obtained from each method for both stations. This research work has never been seen before for the locations and the parameters used in this study.

\section{MATERIALS AND METHODS}

Climate change parameters such as total amount of monthly precipitation $(\mathrm{mm})$, monthly average temperature $\left({ }^{\circ} \mathrm{C}\right)$, monthly average of global radiation $\left(\mathrm{MJm}^{-2}\right)$, monthly average wind speed $(\mathrm{m} / \mathrm{s})$ and monthly average humidity (\%) were considered in this research. There are also other climate change parameters that can be used in order to investigate the trend of the climate change parameters. Willett et al. (2007) used atmospheric water vapor and Tao et al. (2011) used vapor pressure, sunshine duration and potential evaporation as additions to the basic climate change parameter in order to investigate the trend of the climate change parameters. However, only five climate change parameters were considered in this study because most of the studies in recent years have focused on changes in temperature, precipitation (Gocic \& Trajkovic 2013), humidity (Singh et al. 2008), wind speed (Jiang et al.2010) and radiation (Trabea \& Shaltout 2000) only. Besides that, the use of climate change parameters in this study is because it is related to the climate change studies and also because it depends on the availability of the long term historical data provided by the Malaysian Meteorological Department.

The monthly time series data for the parameters of climate change during the years of 1974-2010 was used for analysis due to the availability of data. Comparisons were made among two research stations. First, Senai International Airport $\left(01^{\circ} 38^{\prime} \mathrm{N}, 03^{\circ} 40^{\prime} \mathrm{E}\right)$ and second, Kluang meteorological station $\left(02^{\circ} 01^{\prime} \mathrm{N}, 103^{\circ} 19^{\prime} \mathrm{E}\right)$. Kluang and Senai are located in the north and center of Johor Bahru, respectively. The selection of these two areas is based on the history of heavy rains that hit both areas in the south of Peninsular Malaysia at the end of 2006. In addition, Senai and Kluang recorded the highest amount of rainfall during the heavy rainy seasons, which are 264 and $171 \mathrm{~mm}$ and the highest number of flood victims recorded was 5,645 in Senai and 5,433 in Kluang. Besides that, the selection of the locations is to compare whether they have the same monotonic trend in both locations during the period of the study based on the historical data. This is because, both locations are located at the south of Peninsular Malaysia and had experienced being hit by the heavy rainfall in 2006. Statistical analyses were performed using the R Programming package (version 3.2.5).

\section{MANN-KENDALL TREND TEST}

In this study, the Mann-Kendall trend test was used to see whether there is a monotonic trend in climate change parameters. The Mann-Kendall trend test is a non-parameteric statistical test that is widely used for the analysis of climate trend variables (Mezdour \& Probst 2016; Zhao et al. 2015) and also in the analysis of time series (Pingale et al. 2014). The non-parametric Mann-Kendall statistical method was the main approach employed since it is very useful in hydro-meteorological studies (Altin \& Barak 2014; Araghi et al. 2016). The 
reason for using the non-parametric statistical tests is because, as compared to parametric statistical tests, nonparametric tests were considered more appropriate for data that is not normally distributed and also for filtered data, which is often encountered in hydro-meteorological time series data (Yue \& Pilon 2004; Yue et al. 2002). There are two advantages in using the Mann-Kendall trend. First, it is a non-parametric test and does not require the data to be normally distributed (Karmeshu 2012). Second, this test has a low sensitivity to break significantly due to the non-homogeneous time series (Tabari et al. 2011).

The null hypothesis $H_{0}$ for the Mann-Kendall trend test assumes that there is no trend (data independent and random) and it is tested against the alternative hypothesis $H_{1}$, which assumes the data contains trend (Bihrat \& Mehmet 2003). Probability value (p-value) is used for the hypothesis testing. If the $\mathrm{p}$-value showed a number greater than $\alpha=0.05$, thus, it has failed to reject the null hypothesis and it can be concluded that there is no trend; and if the p-value is lower than $\alpha=0.05, H_{0}$ will be rejected, which means there is a statistically significant trend in the series (Tian 2016). Based on Kendall (1975) and Mann (1945), the calculation for the Mann-Kendall statistical tests is as follows:

$$
\begin{aligned}
& T_{M K}=\frac{S-\operatorname{sgn}(S)}{\sqrt{V(S)}} \\
& \mathrm{s}=\sum_{i=1}^{n-1} \sum_{j=i+1}^{n} \operatorname{sgn}\left(x_{j}-x_{i}\right),
\end{aligned}
$$

where $n$ is the number of data points; $x_{j}$ and $x_{i}$ are the data value in time series; $i$ and $j(j>i)$ is the total dataset; and $\operatorname{sgn}\left(x_{j}-x_{i}\right)$ is the sign function, whereby they are calculated as follows:

$$
\operatorname{sgn}\left(x_{j}-x_{i}\right)=\left\{\begin{array}{r}
+1, \text { if }\left(x_{j}-x_{i}\right)>0 \\
0, \text { if }\left(x_{j}-x_{i}\right)=0 \\
-1, \text { if }\left(x_{j}-x_{i}\right)<0
\end{array}\right.
$$

The variance is calculated as:

$$
\begin{aligned}
& E(S)=0 \\
& \mathrm{~V}(\mathrm{~S})=\frac{\mathrm{n}(\mathrm{n}-1)(2 \mathrm{n}+5)-\sum_{\mathrm{k}=1}^{\mathrm{m}} \mathrm{t}_{\mathrm{k}}\left(\mathrm{t}_{\mathrm{k}}-1\right)\left(2 \mathrm{t}_{\mathrm{k}}+5\right)}{18},
\end{aligned}
$$

where $t_{k}$ is the total bonding point $k$. Standard statistical test $z$ is calculated as,

$$
\mathrm{z}_{\mathrm{s}}=\left\{\begin{aligned}
\frac{\mathrm{S}-1}{\sqrt{\mathrm{V}(\mathrm{S})}}, & \text { if } \mathrm{S}>0 \\
0, & \text { if } \mathrm{S}=0 \\
\frac{\mathrm{S}+1}{\sqrt{\mathrm{V}(\mathrm{S})}}, & \text { if } \mathrm{S}<0
\end{aligned}\right.
$$

and standard statistical Mann-Kendall $z$ is the standard normal distribution with a mean of zero and a variance of one. A positive value (negative) $z$ showed an increase (decrease) trend (Mozejko 2012). $H_{0}$ is rejected if the value $\left|Z_{s}\right|$ is greater than the value $z_{\alpha / 2}$, in which a represents the selected level of significance and so the null hypothesis is not valid with the understanding that there is a significant trend (Motiee \& McBean 2009).

\section{SEN'S SLOPE ESTIMATOR TEST}

If a linear trend is present in a time series, then the true slope (change per unit time) can be estimated by using a simple non-parametric procedure. Sen (1968) developed the non-parametric procedure for estimating the slope of trend in the sample of N pairs of data. The Sen's slope estimator test has been used in this research to estimate the changes for all the climate change parameters. The Sen's slope estimator test is a non-parametric method to estimate the slope of trend in the sample of $N$ pairs of data. Where,

$$
\mathrm{Q}_{\mathrm{i}}=\frac{x_{j}-x_{k}}{j-k} \text { for } i=1, \ldots, N \text {, }
$$

$x_{j}$ and $x_{k}$ are the data values at times $j$ and $k(j>k)$, respectively. If it only has one observation in each time period, then

$$
N=\frac{n(n-1)}{2},
$$

where $n$ is the number of time periods; and if there are multiple observations in one or more time periods, then

$$
N<\frac{n(n-1)}{2},
$$

where $n$ is the total number of observations. The median of slope or Sen's slope estimator is computed as,

$$
Q_{\text {med }}= \begin{cases}Q_{[(N+1) / 2]} & \text { if } \mathrm{N} \text { is odd } \\ \frac{Q_{[N / 2]}+Q_{[(N+2) / 2]}}{2}, & \text { if } \mathrm{N} \text { is even }\end{cases}
$$

If the $Q_{\text {med }}$ gives a positive value, it indicates an upward or increasing trend, while a negative value indicates a downward or decreasing trend.

\section{RESULTS AND DISCUSSION}

The statistical analysis of the parameters of climate change in Senai and Kluang from 1974 until 2010 is shown in Tables 1 and 2. From the analysis, it can be seen that the mean of the monthly average temperature in Senai is $27.49^{\circ} \mathrm{C}$ and in Kluang is $27.73^{\circ} \mathrm{C}$. The mean of monthly average temperature between these two locations is almost the same throughout the 38 years. While for standard deviation, it gives a small value, giving an assumption that the data points are close to the mean value. Malaysia receives heavy rainfall between 2000 and $3000 \mathrm{~mm}$ per 
TABLE 1. Statistical analysis of parameters of climate change in Senai

\begin{tabular}{lccccc}
\hline Parameter & Mean & Standard deviation & Minimum & Maximum & Range \\
\hline Temperature $\left({ }^{\circ} \mathrm{C}\right)$ & 27.49 & 0.69 & 24.5 & 30.1 & 5.6 \\
Precipitation $(\mathrm{mm})$ & 204.2 & 107.16 & 7.9 & 907.2 & 899.3 \\
Wind $(\mathrm{m} / \mathrm{s})$ & 2.7 & 0.7 & 1 & 4.9 & 3.9 \\
Radiation $\left(\mathrm{MJm}^{-2}\right)$ & 14.61 & 2 & 7.43 & 20.94 & 13.51 \\
Humidity $(\%)$ & 86.38 & 2.45 & 77 & 92 & 22 \\
\hline
\end{tabular}

TABLE 2. Statistical analysis of parameters of climate change in Kluang

\begin{tabular}{lccccc}
\hline Parameter & Mean & Standard deviation & Minimum & Maximum & Range \\
\hline Temperature $\left({ }^{\circ} \mathrm{C}\right)$ & 27.73 & 0.76 & 25.59 & 29.75 & 4.16 \\
Precipitation $(\mathrm{mm})$ & 176.5 & 107.69 & 4.8 & 775.6 & 770.8 \\
Wind $(\mathrm{m} / \mathrm{s})$ & 2.1 & 0.9 & 0.6 & 5.2 & 4.6 \\
Radiation $\left(\mathrm{MJm}^{-2}\right)$ & 15.87 & 1.64 & 9.9 & 21.4 & 11.5 \\
Humidity $(\%)$ & 85.98 & 3.09 & 76 & 99 & 23 \\
\hline
\end{tabular}

year. According to this analysis, the mean for precipitation in Senai is $204.2 \mathrm{~mm}$ while for Kluang is $176.5 \mathrm{~mm}$. However, the total amount of monthly rainfall is very high. The maximum precipitation recorded in Senai is $907.2 \mathrm{~mm}$ and in Kluang is $775.6 \mathrm{~mm}$. Eventually, it gives a high value for the standard deviation for both locations, which is $107.16 \mathrm{~mm}$ for Senai and $107.69 \mathrm{~mm}$ for Kluang. This is not surprising since Senai and Kluang have severe flood incidents in 2006 and it gives a high value for the standard deviation as compared to other parameters. By referring to the parameter of wind speed, the mean for the monthly average wind speed in both locations is quite low. This is true according to the Malaysian Meteorological Department (2014), who claimed that the wind speed in Malaysia is low and keeps changing directions. The gap between the minimum and the maximum values of wind speed is not too big and it has resulted in a low value for the standard deviation.

The maximum number for the average monthly radiation in Senai and Kluang is $20.94 \mathrm{MJm}^{-2}$ and 21.4 $\mathrm{MJm}^{-2}$, respectively. It can be said that radiation in these two locations is still in the normal range. Normally, the amount of global radiation is from $1 \mathrm{MJm}^{-2}$ to $35 \mathrm{MJm}^{-2}$. The amount is higher during sunny days and lower during cloudy and rainy days. While for humidity, Senai and Kluang received a high relative humidity, where the maximum number of average monthly relative humidity in these two locations is $92 \%$ for Senai and $99 \%$ for Kluang. Malaysia normally receives a high relative humidity of not more than $80 \%$ (Malaysian Meteorological Department 2017).

The results of the Mann-Kendall trend test and Sen's slope estimator test for Kluang and Senai can be seen in Tables 3 and 4. From Table 3, it can be seen that precipitation is the only parameter that indicated no significant trend in Senai. Meanwhile, other parameters indicated a monotonic trend. The same goes to Kluang, whereby the precipitation indicated no significant trend, while the radiaition indicated no trend only from Sen's slope estimator. However, other parameters have a trend according to both results. If we refer to the Tau value ( $Z$ ), both locations show an increasing trend for the temperature when the Tau value $(Z)$ gives a positive value, which are 0.236 and 0.354 . While for the Sen's slope estimator test, it gives a value of 0.149 and 0.0201 . Meanwhile, for wind speed and humidity, both locations show a decreasing trend when it gives a negative Tau value $(Z)$ and negative Sen's slope value. For radiation in Senai, it shows a decreasing trend based on the Tau value $(Z)$ and Sen's slope value. However, the radiation in Kluang shows no trend when it gives a p-value of 0.765 and 0.6943 .

According to the results, it can be depicted that some of the parameters show a monotonic trend, while some do not

TABLE 3. Significant test results for Senai

\begin{tabular}{lcccccc}
\hline \multirow{2}{*}{ Parameter } & \multicolumn{3}{c}{ Mann-Kendall trend test } & \multicolumn{2}{c}{ Sen's slope } \\
\cline { 2 - 7 } & Tau value, $\mathrm{Z}$ & $\mathrm{p}$-value & Test conclusion & Sen's value & $\mathrm{p}$-value & Test conclusion \\
\hline Temperature $\left({ }^{\circ} \mathrm{C}\right)$ & 0.236 & $2.22 \mathrm{e}-16$ & Monotonic trend & 0.149 & $2.98 \mathrm{e}-06$ & Monotonic trend \\
Precipitation $(\mathrm{mm})$ & 0.061 & 0.06 & No trend & 0.052 & 0.1052 & No trend \\
Wind $(\mathrm{m} / \mathrm{s})$ & -0.308 & $2.22 \mathrm{e}-16$ & Monotonic trend & -0.202 & $-2.45 \mathrm{e}-10$ & Monotonic trend \\
Radiation ) & -0.273 & $2.93 \mathrm{e}-10$ & Monotonic trend & -0.169 & -0.0001 & Monotonic trend \\
Humidity $(\%)$ & -0.252 & $5.73 \mathrm{e}-14$ & Monotonic trend & -0.179 & $-2.19 \mathrm{e}-08$ & Monotonic trend \\
\hline
\end{tabular}


TABLE 4. Significant test results for Kluang

\begin{tabular}{|c|c|c|c|c|c|c|}
\hline \multirow{2}{*}{ Parameter } & \multicolumn{3}{|c|}{ Mann-Kendall trend test } & \multicolumn{3}{|c|}{ Sen's slope } \\
\hline & Tau value, $\mathrm{Z}$ & p-value & Test conclusion & Sen's value & $\mathrm{p}$-value & Test conclusion \\
\hline Temperature $\left({ }^{\circ} \mathrm{C}\right)$ & 0.354 & $2.22 \mathrm{e}-16$ & Monotonic trend & 0.201 & 0.0001 & Monotonic trend \\
\hline Precipitation (mm) & 0.055 & 0.0819 & No trend & 0.046 & 0.1511 & No trend \\
\hline Wind $(\mathrm{m} / \mathrm{s})$ & -0.553 & $2.22 \mathrm{e}-16$ & Monotonic trend & -0.352 & -0.0001 & Monotonic trend \\
\hline Radiation ) & 0.0152 & 0.765 & No trend & 0.019 & 0.6943 & No trend \\
\hline Humidity (\%) & -0.18 & $6.68 \mathrm{e}-08$ & Monotonic trend & -0.119 & -0.0002 & Monotonic trend \\
\hline
\end{tabular}

have a monotonic trend. Investigating the trend of climate change parameters is very important as early detection for future analysis and forecasting of climate change have become so important to global issues, especially in global warming, green house issues and ozone depletion. The knowledge of how and where the climate has varied and is changing is crucial in developing successful coping strategies for agriculture and eco-systems in general (Heim 2015). When the result shows any significant monotonic trend for the climate change parameters, it can give a big insight to the researcher in order to determine and make an early judgement about the climate change in Malaysia. However, if the parameters do not show any monotonic trend, future investigation is needed in order to know the overall general trend for the parameters through the years. Early detection is crucial as it can give little information about the parameters and how far it can affect the climate change in future.

Arising from the result, the temperature shows a positive trend throughout the years for both locations. According to Yunling and Yiping (2005), they had indicated that temperature has increased from 1960 to 2000 at 19 stations along the Lancang River (China). Meanwhile, Ceppi et al. (2012) showed that temperature has increased in Switzerland from 1959 to 2008. A study in Malaysia by Hashim (2010) had shown that there is an increasing trend for temperature from 1970 to 2005 in the urban areas. As reported by the Director of the Malaysian Meteorological Department in the local newspaper Sinar Harian (2013), he confirmed that the increase in of temperature might be due to the Southwest Monsoon, which usually brings hot and dry weather conditions. In addition, the temperature and heat have increased with the advent of the tropical storm in the Philippines and low pressure from the Indian Ocean.

However, wind and humidity show a negative trend for both locations. Satari et al. (2015) mentioned in their study that meteorological conditions such as wind are very much dominated by the monsoon season. A study on wind speed trend had been done by Jiang et al. (2010) in China from 1956 to 2004 and they concluded that they all showed decreasing trends over broad areas of China. While for radiation, a negative trend was found only for Senai. However, no trend is recorded for radiation in Kluang. Despite such interesting results, it has a different conclusion as compared to other parameters in both locations. A study conducted by Liu and Scott (2001) mentioned that radiation is influenced by temperature and frequency of rainfall. In this study, the varying results for radiation in both locations might be due to temperature and precipitation. Since this study is focused on the trend, it is recommended to investigate the correlation between radiation with other climate change parameters for future research.

\section{CONCLUSION}

This research is pertaining to the trends analysis for climate change parameters in the Senai and Kluang areas. Understanding of the climate change trend is an important requirement for planning and management, especially for water resources, construction projects and plantation issues. From this study, it gives some insight about the trend pattern in climate change parameters in both locations. The parameters are temperature, precipitation, wind speed, global radiation and relative humidity. With this little effort of research, it might give some contribution in understanding the trend of climate change variables.

A statistical analysis was made as a first step in understanding the data. The Mann-Kendall trend test is a suitable technique to be used since it is one of the techniques that are widely used for environmental and climate studies. However, the Sen' slope estimator test has also been used in this research to estimate the trend for all the climate change parameters and it gives a good result like the Mann-Kendall trend test result. There is not much gap difference from the results shown in both methods. The Sen's slope estimator test gave a lower estimated value as compared to the Mann-Kendall trend test. Overall, the results of the Mann-Kendall trend test and Sen's slope estimator test gave a good result in the detection of the trend for climate change parameters. Both methods can be used in predicting and estimating a trend especially for climate change parameters.

In conclusion, the findings from this study may give useful information regarding the trend of climate change parameters in Senai and Kluang. Additionally, this trend analysis can be extended for further analysis, such as in identifying significant correlations among the climate change parameter as some of the parameters give different results in both locations such as radiation. Besides that, the analysis of monthly trends for each parameter can also be considered for future analysis. 


\section{ACKNOWLEDGEMENTS}

The authors would like to acknowledge the Earth Observation Center, Universiti Kebangsaan Malaysia for providing the climate change data for this research. Besides that, the authors would like to thank the Ministry of Higher Education (MOHE), Malaysia for supporting this research via research grant, FRGS/1/2016/STG06/UKM/02/1.

\section{REFERENCES}

Altin, T.B.\& Barak, B. 2014. Changes and trends in total yearly precipitation of the Antalya district, Turkey. Procedia Social and Behavioral Sciences 120: 586-599.

Amirullah, H.A. 2011. Masalah banjir kilat di Kuala Lumpur: Keberkesanan kaedah pencegahan banjir.

http://webcache.googleusercontent.com/ search? q =cache:87IXK61 MI6oJ: www.efka. utm.my/thesis/IMAGES/3PS M/2010/JKS-3/ hamidanuarsx 060217 awj04d10ttt.pdf $+\& \mathrm{~cd}=+$ $\& c d=9 \& h l=e n \& c t=c l n k \& g l=m y$. Accessed on 23 May 2016.

Anghileri, D., Pianosi, F. \& Soncini-Sessa, R. 2014. Trend detection in seasonal data: From hydrology to water resources. Journal of Hydrology 511: 171-179.

Apurv, T., Mehrotra, R., Sharma, A., Goyal, M.K. \& Dutta, S. 2015. Impact of climate change on floods in the Brahmaputra basin using CMIP5 decadal predictions. Journal of Hydrology 527: 281-291.

Araghi, A., Adamowski, J. \& Rajabi, M. 2016. Detection of trends in days with thunderstorms in Iran over the past five decades. Atmospheric Research 172-173: 174-185.

Bachelet, D., Ferschweiler, K., Sheehan, T. \& Strittholt, J. 2016. Climate change effects on southern California deserts. Journal of Arid Environments 127: 17-29.

Bihrat, O. \& Mehmet, B. 2003. The power of statistical tests for trend detection. Journal of Engineering and Environmental Sciences 27: 247-251.

Ceppi, P., Scherrer, S.C., Fischer, A.M. \& Appenzeller, C. 2012. Revisiting Swiss temperature trends 1959 - 2008. International Journal of Climatology 32(2): 203-213.

Chandler, R. \& Scott, M. 2011. Statistical Methods for Trend Detection and Analysis in the Environmental Sciences. United Kingdom: John Wiley \& Sons, Ltd.

Federal Department of Town and Country Planning Peninsular Malaysia. 2011. Pengurusan fizikal dan usaha mengelakkan banjir. http://www.townplan.gov.my/content.php?ID=200. Accessed on 1 July 2016.

Fonseca, D., Carvalho, M.J. \& Rocha, A. 2016. Recent trends of extreme temperature indices for the Iberian Peninsula. Physics and Chemistry of the Earth 94: 66-76.

Gasim, M.B., Surif, S., Mokhtar, M., Toriman, M.E., Rahim, S.A. \& Bee, C.H. 2010. Analisis banjir Disember 2006: Tumpuan di kawasan Bandar Segamat, Johor. Sains Malaysiana 39(3): 353-361.

Gocic, M. \& Trajkovic, S. 2013. Analysis of changes in meteorological variables using Mann-Kendall and Sen's slope estimator statistical tests in Serbia. Global and Planetary Change 100: 172-182.

Hashim, N.M. 2010. The impact of global warming trends on urban livability in Malaysia: An analysis. Malaysian Journal of Society and Space 6(2): 72-88.

Haskett, J.D., Pachepsky, Y.A. \& Acock, B. 2000. Effect of climate and atmospheric change on soybean water stress: A study of Iowa. Ecological Modelling 135(2-3): 265-277.
Heim, R.R. 2015. An overview of weather and climate extremes - Products and trends. Weather and Climate Extremes 10(Part B): 1-9.

Ikhwanuddin, M.E.M., Amal, M.N.A., Shohaimi, S., Hasan, H.H. \& Jamil, N.R. 2016. Environmental influences on fish assemblages of the upper Sungai Pelus, Kuala Kangsar, Perak, Malaysia. Sains Malaysiana 45(10): 1487-1495.

Jamaludin, S., Mohd Deni, S., Wan Zin, W.Z. \& Jemain, A.A. 2010. Trends in Peninsular Malaysia rainfall data during the southwest monsoon and northeast monsoon seasons: 1975 2004. Sains Malaysiana 39(4): 533-542.

Jarvis, A., Lane, A. \& Hijmans, R.J. 2008. The effect of climate change on crop wild relatives. Agriculture, Ecosystems \& Environment 126(1-2): 13-23.

Jiang, Y., Luo, Y., Zhao, Z. \& Tao, S. 2010. Changes in wind speed over China during 1956 - 2004. Theoretical and Applied Climatology 99: 421-430.

Karmeshu, N. 2012. Trend detection in annual temperature \& precipitation using the Mann Kendall test - A case study to assess climate change on select states in the Northeastern United States. Master of Environmental Studies Capstone Projects. 47. University of Pennysylvania (Unpublished).

Kendall, M. 1975. Rank Correlation Methods. London: Charles Griffin.

Liu, D.L. \& Scott, B.J. 2001. Estimation of solar radiation in Australia from rainfall and temperature observations. Agricultural and Forest Meteorology 106(1): 41-59.

Malaysian Meteorological Department. 2017. http://www.met. gov.my. Accessed on 11 May 2017.

Malaysian Meteorological Department. 2014. http://www.met. gov.my. Accessed on 6 May 2014.

Mann,H.B. 1945. Nonparametric tests against trend. Econometrica 13: 245-259.

Mezdour, A. \& Probst, A. 2016. Contrasted spatial and long-term trends in precipitation chemistry and deposition fl uxes at rural stations in France. Atmospheric Environment 146: 28-43.

Mondal, A., Kundu, S. \& Mukhopadhyay, A. 2012. Rainfall trend analysis by Mann-Kendall test: A case study of NorthEastern part of Cuttack District, Orissa. International Journal of Geology, Earth and Environmental Sciences 2(1): 70-78.

Motiee, H. \& McBean, E. 2009. An assessment of long-term trends in hydrologic components and implications for water levels in Lake Superior. Hydrology Research 40(6): 564-579.

Mozejko, J. 2012. Detecting and estimating trends of water quality parameters. Water Quality Monitoring and Assessment, edited by Dr. Voudouris. InTech. www.intechopen.com/books/ water-quality-monitoring-and-assessment/detecting-andestimating-trends-of-water-quality-parameters.

Onyutha, C., Tabari, H., Taye, M.T., Nyandwaro, G.N. \& Willems, P. 2015. Analyses of rainfall trends in the Nile River Basin. Journal of Hydro-Environment Research 13: 36-51.

Pin, K.F., Pereira, J.J. \& Aziz, S. 2013. Platforms of climate change: An evolutionary perspective and lessons for Malaysia. Sains Malaysiana 42(8): 1027-1040.

Pingale, S.M., Khare, D., Jat, M.K. \& Adamowski, J. 2014. Spatial and temporal trends of mean and extreme rainfall and temperature for the 33 urban centers of the arid and semi-arid state of Rajasthan, India. Atmospheric Research 138: 73-90.

Rianna, G., Zollo, A., Tommasi, P., Paciucci, M., Comegna, L. \& Mercogliano, P. 2014. Evaluation of the effects of climate changes on landslide activity of Orvieto clayey slope. Procedia Earth and Planetary Science 9: 54-63. 
Rosmann, T., Domínguez, E. \& Chavarro, J. 2016. Comparing trends in hydrometeorological average and extreme data sets around the world at different time scales. Journal of Hydrology: Regional Studies 5: 200-212.

Satari, S.Z., Zubairi, Y., Hassan, S. \& Hussin, A. 2015. Some statistical characteristic of malaysian wind direction recorded at maximum wind speed : 1999-2008. Sains Malaysiana 44(10): 1999-2008

Sen, P.K. 1968. Estimates of the regression coefficient based on Kendall's Tau. Journal of the American Statistical Association 63(324): 1379-1389.

Shaaban, A.J. 2013. Impact of Climate Change on Malaysia. Bangi: Institut Penyelidikan Hidraulik Kebangsaan Malaysia.

Shibuya, T. \& Croxford, B. 2016. The effect of climate change on office building energy consumption in Japan. Energy and Buildings 117: 1-11.

Sinar Harian. 2013. Malaysia dilanda "cuaca panas." Kuala Lumpur. http://www.sinarharian.com.my/malaysia-dilandacuaca-panas-1.172790. Accessed on 13 July 2015.

Singh, P., Kumar, V., Thomas, T. \& Arora, M. 2008. Changes in rainfall and relative humidity in river basins in northwest and central India. Hydrological Processes 2992: 2982-2992.

Soon, T. \& Ransangan, J. 2016. Effects of environmental conditions and nutrients on the occurrence and distribution of potentially harmful phytoplankton in Mesotrophic water. Sains Malaysiana 45(6): 865-877.

Tabari, H., Marofi, S., Aeini, A., Talaee, P.H. \& Mohammadi, K. 2011. Trend analysis of reference evapotranspiration in the western half of Iran. Agricultural and Forest Meteorology 151(2): 128-136.

Tao, H., Gemmer, M., Bai, Y., Su, B. \& Mao, W. 2011 . Trends of streamflow in the Tarim River Basin during the past 50 years: Human impact or climate change ? Journal of Hydrology 400(1-2): 1-9.

The Star. 2006. Typoon Utor to blame. Cyberjaya. http://www. thestar.com.my/story $/$ file $=\% 2 \mathrm{~F} 2006 \% 2 \mathrm{~F} 12 \% 2 \mathrm{~F} 21 \% 2 \mathrm{Fnati}$ on\%2F16380186. Accessed on 24 August 2016.

Tian, Q., Prange, M. \& Merkel, U. 2016. Precipitation and temperature changes in the major Chinese river basins during 1957 - 2013 and links to sea surface temperature. Journal of Hydrology 536: 208-221.
Trabea, A.A. \& Shaltout, M.A.M. 2000. Correlation of global solar radiation with meteorological parameters over Egypt Renewable Energy 21: 297-308.

Vo, N.D., Gourbesville, P., Vu, M.T., Raghavan, S.V. \& Liong, S.Y. 2015. A deterministic hydrological approach to estimate climate change impact on river flow: Vu Gia-Thu Bon catchment, Vietnam. Journal of Hydro-environment Research 11: $59-74$

Willett, K.M., Gillett, N.P., Jones, P.D. \& Thorne, P.W. 2007. Attribution of observed surface humidity changes to human influence. Nature 449: 710-712.

Yue, S. \& Pilon, P. 2004. A comparison of the power of the $t$ test, Mann-Kendall and bootstrap tests for trend detection. Hydrological Sciences 49: 21-38.

Yue, S., Pilon, P. \& Cavadias, G. 2002. Power of the MannKendall and Spearman's rho tests for detecting monotonic trends in hydrological series. Journal of Hydrology 259: 254-271.

Yunling,H.\& Yiping,Z. 2005. Climate change from 1960 to 2000 in the Lancang River Valley, China. Mountain Research and Development 25(4): 341-348.

Zhao, J., Huang, Q., Chang, J., Liu, D., Huang, S. \& Shi, X. 2015. Analysis of temporal and spatial trends of hydro-climatic variables in the Wei River Basin. Environmental Research 139: 55-64.

Department of Civil and Structural Engineering Faculty of Engineering and Build Environment Universiti Kebangsaan Malaysia 43600 UKM Bangi, Selangor Darul Ehsan Malaysia

*Corresponding author; email: fir@ukm.edu.my

Received: 29 January 2017

Accepted: 29 August 2017 